\title{
Three-gene signature predicts disease progression of non-muscle invasive bladder cancer
}

\author{
PILDU JEONG $^{1}$, YUN-SOK HA ${ }^{1}$, IN-CHANG CHO ${ }^{2}$, SEOK-JOONG YUN ${ }^{1}$, EUN SANG YOO ${ }^{3}$, ISAAC YI KIM ${ }^{7}$, \\ YUNG HYUN CHOI ${ }^{4,5}$, SUNG-KWON MOON ${ }^{6}$ and WUN-JAE KIM ${ }^{1}$ \\ ${ }^{1}$ Department of Urology, College of Medicine, Chungbuk National University, Cheongju, Chungbuk; ${ }^{2}$ Center for \\ Prostate Cancer, Goyang; ${ }^{3}$ Department of Urology, School of Medicine, Kyungpook National University, Daegu; \\ ${ }^{4}$ Department of Biochemistry, Dongeui University College of Oriental Medicine, Busan; ${ }^{5}$ Department of Biomaterial \\ Control, Dongeui University Graduate School, Busan; ${ }^{6}$ Department of Food and Biotechnology, Chungju \\ National University, Chungju, Republic of Korea; ${ }^{7}$ Section of Urologic Oncology, The Cancer \\ Institute of New Jersey, Robert Wood Johnson Medical School, New Brunswick, NJ, USA
}

Received December 17, 2010; Accepted April 27, 2011

DOI: $10.3892 / \mathrm{ol} .2011 .309$

\begin{abstract}
The clinical grades and staging methods currently employed for bladder cancer (BC) are inadequate for assessing treatment outcomes for non-muscle invasive bladder cancer (NMIBC). We have developed a clinically applicable quantitative real-time PCR (qPCR) gene signature to predict the progression of NMIBC. Three genes not previously described for $\mathrm{BC}$ were selected from our published progression-related gene classifier data set. Data were drawn from a previous study population and from new cases. Primary NMIBC tissue specimens $(n=193)$ were analyzed by qPCR. Risk scores were then used to rank specimens into high- and low-risk signature groups based on their gene expression. The Kaplan-Meier method and a multivariate Cox regression model were used to identify the prognostic value of the three-gene signature for both recurrence and progression. The Kaplan-Meier estimates
\end{abstract}

Correspondence to: Dr Sung-Kwon Moon, Department of Food and Biotechnology, Chungju National University, 123 Geomdan-ri Iryu-myeon, Chungju, Chungbuk 380-702, Republic of Korea

E-mail: sumoon66@dreamwiz.com

Dr Wun-Jae Kim, Department of Urology, College of Medicine, Chungbuk National University, 62 Kaeshin-dong, Heungduk-ku, Cheongju, Chungbuk 361-711, Republic of Korea

E-mail:wjkim@chungbuk.ac.kr

Abbreviations: $\mathrm{BC}$, bladder cancer; NMIBC, non-muscle invasive bladder cancer; MIBC, muscle invasive bladder cancer; CELSR3, cadherin EGF LAG seven-pass G-type receptor 3; $K I F 1 A$, kinesin family member $1 \mathrm{~A}$; $C O C H$, coagulation factor $\mathrm{C}$ homolog; qPCR, quantitative real-time PCR; TUR, transurethral resection; CIS, carcinoma in situ; GAPDH, glyceraldehyde-3phosphate dehydrogenase

Key words: bladder cancer, cadherin EGF LAG seven-pass G-type receptor 3 , coagulation factor $\mathrm{C}$ homolog, gene signature, kinesin family member $1 \mathrm{~A}$, prognosis, quantitative real-time PCR revealed significant differences in time-to-recurrence and progression between low- and high-risk signatures (log-rank test, $\mathrm{p}=0.011$ and $\mathrm{p}<0.001$, respectively). The multivariate Cox regression analysis showed that the three-gene risk signature is an independent predictor of bladder tumor progression (hazard ratio, 4.268; 95\% $\mathrm{CI}, 1.542-11.814 ; \mathrm{p}=0.005$ ). In conclusion, our three-gene signature was found to be closely associated with progression among patients with NMIBC.

\section{Introduction}

Bladder cancer (BC), the incidence and mortality of which increases directly with age, is a heterogeneous disease that affects approximately 68,000 people in the United States annually (1). In Korea, BC is the second most common urological malignancy and is about five times more common in male as compared to female individuals (2). Patients diagnosed with non-muscle invasive bladder cancers (NMIBC) may have indolent, albeit recurrent, disease. However, NMIBC patients are required to receive frequent cystourethroscopy, which is inconvenient for patients. Additionally, they may experience progression to muscle invasive bladder cancer (MIBC), which potentially has a narrow window-of-cure and requires aggressive treatment (3). Therefore, predicting the course of the disease is of great value to both patients and urologists, in order for adequate management of NMIBC to occur. For example, early radical cystectomy has a superior 5-year survival rate compared to bladder-sparing surgery (4). The development of accurate and reliable biological markers would be useful for assessing aggressiveness and for predicting the prognosis of NMIBC.

Previously, we undertook a microarray analysis of specimens derived from 103 primary NMIBC patients and identified an eight-gene progression-related gene classifier (5). Although there have been numerous attempts to establish prognostic markers for NMIBC (3,6-8), the limited value of current markers means that new predictive indicators of $\mathrm{BC}$ outcome are urgently required. Due to the molecular and cellular 
heterogeneity of most cancers, and the subsequent variability in biological behavior, a single pathway or gene marker, may have inherent limitations in terms of predicting cancer outcome.

In this study, three genes were selected to yield a signature not previously described for BC: the cadherin EGF LAG sevenpass G-type receptor 3 (CELSR3), kinesin family member $1 \mathrm{~A}$ $(K I F 1 A)$ and coagulation factor $\mathrm{C}$ homolog $(\mathrm{COCH})$. Using quantitative real-time PCR (qPCR), the up-regulated expression of the mRNA for these genes was shown to be associated with disease progression. The relationship between this threegene signature and NMIBC outcomes was investigated using data obtained from a previous study population and from new cases, all with an extended follow-up period.

\section{Materials and methods}

Patients. A total of 193 primary NMIBC patients with transitional cell carcinoma of the urinary bladder treated with transurethral resection (TUR) between 1995 and 2008 were eligible for inclusion in the present study. A minimum follow-up period of 6 months was required (unless recurrence and/or progression occurred prior to this 6-month period). To make the study population more homogeneous, patients with concomitant carcinoma in situ (CIS) and those who had undergone radical cystectomy were excluded. All tumors were macrodissected, typically within $15 \mathrm{~min}$ of surgical resection. Each BC specimen was confirmed by a pathological analysis of fresh frozen sections obtained from part of the TUR tissue samples. Samples were then frozen in liquid nitrogen and stored at $-80^{\circ} \mathrm{C}$ until required. The collection and analysis of all samples was approved by the local institutional review board and informed consent was obtained from each subject.

A second TUR was performed 2-4 weeks after the initial resection if a $\mathrm{BC}$ specimen did not include proper muscle tissue, or when a high-grade tumor was detected (9). Patients with a T1 tumor, multiple tumors, large tumors $(\geq 3 \mathrm{~cm}$ in diameter), or a high-grade Ta tumor received one cycle of intravesical treatment (BCG or mitomycin-C) $(9,10)$. If a patient refused intravesical therapy, it was not administered after TUR. Response to treatment was assessed by cystoscopy and urinary cytology. Patients who were disease-free within 3 months after treatment were assessed every 3 months for the first 2 years and every 6 months thereafter $(9,10)$. Tumors were staged and graded according to the 2002 TNM classification and the 1973 WHO grading system, respectively $(9,11)$. Recurrence was defined as relapse of the primary NMIBC with a lower, or the same, pathological stage, and progression was defined as disease with a higher TNM stage upon relapse.

RNA extraction and construction of cDNA. RNA was isolated from tissue using $1 \mathrm{ml}$ of TRIzol reagent (Invitrogen, Carlsbad, CA, USA) and homogenized in a $5 \mathrm{ml}$ glass tube. The homogenate was transferred to a $1.5 \mathrm{ml}$ tube and mixed with $200 \mu \mathrm{l}$ of chloroform. After incubation for $5 \mathrm{~min}$ at $4^{\circ} \mathrm{C}$, the homogenate was centrifuged for $13 \mathrm{~min}$ at $13,000 \mathrm{x} \mathrm{g}$ at $4^{\circ} \mathrm{C}$. The upper aqueous phase was transferred to a clean tube and then $500 \mu \mathrm{l}$ of isopropanol was added. The mixture was incubated for $60 \mathrm{~min}$ at $4^{\circ} \mathrm{C}$, and the tube was centrifuged for $8 \mathrm{~min}$ at $13,000 \mathrm{x} \mathrm{g}$ at $4^{\circ} \mathrm{C}$. The upper aqueous phase was discarded and mixed with $500 \mu 1$ of $75 \%$ ethanol, and centrifuged for $5 \mathrm{~min}$ at $13,000 \mathrm{x} \mathrm{g}$ at $4^{\circ} \mathrm{C}$. After discarding the upper aqueous layer, the pellet was dried at room temperature, dissolved in diethylpyrocarbonate (DEPC)-treated water, and then stored at $-80^{\circ} \mathrm{C}$. The quality and integrity of the RNA were confirmed by agarose gel electrophoresis and ethidium bromide staining followed by visual inspection under ultraviolet light. cDNA was prepared from $1 \mu \mathrm{g}$ of total-RNA using a First-Strand cDNA Synthesis kit (Amersham Biosciences Europe GmbH, Freiburg, Germany) according to the manufacturer's instructions.

Quantitative real-time PCR. qPCR amplification was performed using a Rotor-Gene 6000 instrument (Corbett Research, Mortlake, Australia) to quantify the expression of CELSR3, KIFIA and COCH. qPCR assays were carried out in micro-reaction tubes (Corbett Research) using SYBR-Premix Ex Taq (Takara, Otsu, Japan). The primers used in the amplification were: CELSR3 (129 bp), sense 5'-CTC CAT GTT GGT GAC TGT CAC-3' and antisense 5'-TCC TGC CAC ATG TTC TCA AG-3'; KIF1A (157 bp), sense 5'-AAG AAC CAA GGG CAA CCT TCG-3' and antisense 5'-CTC CAT TCA TGT TGG TGG CC-3'; COCH (134 bp), sense 5'-AGA AAG CAG ATG TCC TCT GC-3' and antisense 5'-TCC CCC TGA GTT GCT GAT TA-3'. The PCR reaction was performed in a final volume of $10 \mu \mathrm{l}$ consisting of $5 \mu \mathrm{l}$ of $2 \mathrm{X}$ SYBR-Premix Ex Taq buffer, $0.5 \mu \mathrm{l}$ each of 5'- and 3'- primer (10 pmol $/ \mu \mathrm{l})$, and $1 \mu \mathrm{l}$ of the cDNA sample. The product was purified with a QIAquick Extraction kit (Qiagen, Hilden, Germany), quantified with a spectrophotometer (Perkin Elmer MBA2000, Fremont, CA, USA), and then sequenced with an automated laser fluorescence sequencer (ABI PRISM 3100 Genetic Analyzer, Foster City, WI, USA). Ten-fold serial dilutions of a known concentration of the product (from 100 to $0.1 \mathrm{pg}$ / $\mu 1)$ were used to establish the standard curve for qPCR. The qPCR conditions were: 1 cycle for $20 \mathrm{sec}$ at $96^{\circ} \mathrm{C}$, followed by 40 cycles of $2 \mathrm{sec}$ at $96^{\circ} \mathrm{C}$ for denaturation, $15 \mathrm{sec}$ at $60^{\circ} \mathrm{C}$ for annealing, and $15 \mathrm{sec}$ at $72^{\circ} \mathrm{C}$ for extension. The melting program was performed at $72-95^{\circ} \mathrm{C}$ with a heating rate of $1^{\circ} \mathrm{C}$ per $45 \mathrm{sec}$. Spectral data were captured and analyzed using Rotor-Gene Real-Time Analysis Software 6.0 Build 14 (Corbett Research). All of the samples were run in triplicate. Glyceraldehyde-3-phosphate dehydrogenase $(G A P D H)$ was analyzed as an endogenous RNA reference gene and gene expression was normalized to the expression of GAPDH.

Statistical analysis. Data from the three genes were natural log-transformed to normalize the highly skewed distribution of mRNA expression levels (12), and a risk score for recurrence and progression was calculated for each patient (the sum of the levels of expression of each gene multiplied by the corresponding regression coefficients) (5,13-18). Receiver operating characteristic (ROC) curves were used to determine the optimal cut-off point for each risk score that yielded the highest combined sensitivity and specificity for recurrence and progression, respectively. Using these values, patients were classified into high- or low-risk signature groups. The Kaplan-Meier method was used to estimate time-torecurrence and progression, and differences were assessed using log-rank statistics. The prognostic value of the threegene risk signature, in terms of recurrence and progression, 
Table I. Baseline characteristics of primary non-muscle invasive bladder cancer patients.

\begin{tabular}{lc}
\hline Variables & No. of patients $(\%)$ \\
\hline Age (years), median (range) & $67.0(24.0-91.0)$ \\
Median follow-up in months (range) & $44.9(6.1-194.5)$ \\
Gender & \\
Male & $157(81.3)$ \\
Female & $36(18.7)$ \\
Grade & \\
G1 & $67(34.7)$ \\
G2 & $101(52.3)$ \\
G3 & $25(13.0)$ \\
Stage & \\
Ta & $71(36.8)$ \\
T1 & $122(63.2)$ \\
Size & \\
$<3 \mathrm{~cm}$ & $109(56.5)$ \\
$\geq 3 \mathrm{~cm}$ & $84(43.5)$ \\
Number & \\
Single & $111(57.5)$ \\
Multiple & $82(43.5)$ \\
Intravesical therapy & \\
No & $80(41.5)$ \\
Yes & $113(58.5)$ \\
\hline
\end{tabular}

was analyzed using multivariate Cox proportional hazard regression models. Statistical analysis was performed using SPSS 12.0 software (SPSS, Chicago, IL, USA). P $<0.05$ was considered to be statistically significant.

\section{Results}

Baseline characteristics. The median follow-up period after surgery was 44.9 months (range 6.1-194.5) and the median age was 67.0 years (range 24.0-91.0). Of the 193 patients, $71(36.8 \%)$ experienced recurrence and $20(10.4 \%)$ experienced progression. The mean intervals for recurrence and progression were 41.2 months (median 22.1; range 1.4-164.4) and 55.3 months (median 44.9; range 6.1-194.5), respectively. Other clinical and pathological characteristics of the patients are shown in Table I.

Prognostic value of three-gene risk signature for recurrence and progression. Kaplan-Meier estimates revealed significant differences in time-to-recurrence and progression between low- and high-risk signatures (log-rank test, $\mathrm{p}=0.011$ and $\mathrm{p}<0.001$, respectively) (Fig. 1A and B). The multivariate Cox regression analysis revealed that the three-gene signature was an independent predictor of bladder tumor progression (hazard ratio, 4.268; 95\% CI, 1.542-11.814; $\mathrm{p}=0.005$ ) (Table II). However, the multivariate survival analysis showed that the three-gene signature was not an independent predictor of tumor recurrence.
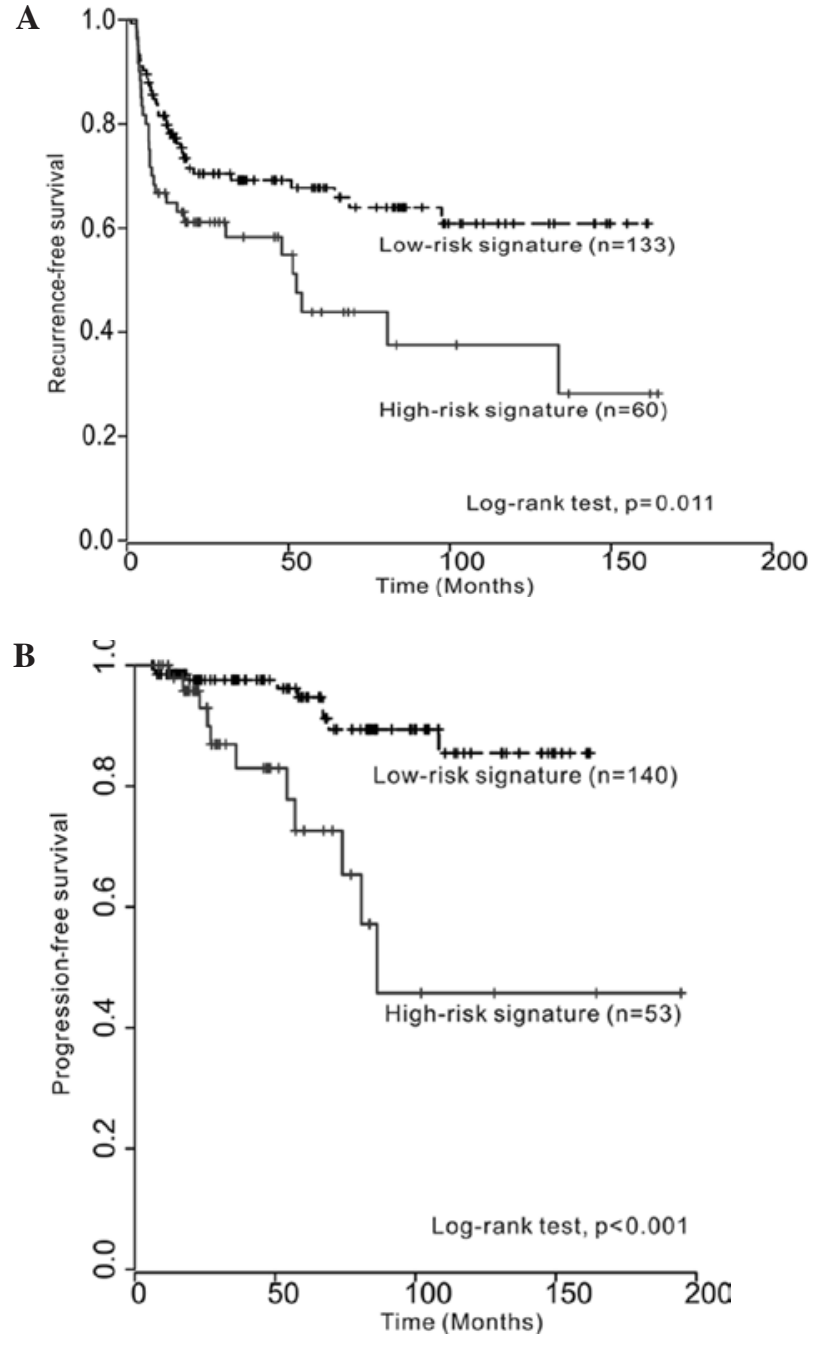

Figure 1. Kaplan-Meier curves showing (A) time to recurrence and (B) time to progression between low- and high-risk signatures (log-rank test, $\mathrm{p}=0.011$ and $\mathrm{p}<0.001$, respectively).

\section{Discussion}

Our experimental approach was based on an initial microarray gene expression analysis of 103 randomly selected primary NMIBC specimens (5). The number of NMIBC samples was progressively increased and three genes not previously described in BC were selected. Specifically, patients designated as high-risk by the three-gene signature were more likely to show progression of NMIBC, had a strong hazard ratio (4.268) following multivariate analysis, and had various known clinical risk factors, including age, tumor size, number of tumors, T-category, tumor grade and intravesical therapy. This result provided evidence that a gene signature was able to provide additional risk stratification beyond pathology, which is particularly useful due to the inter-observer variability inherent in tumor staging and grading $(19,20)$.

CELSR 3 is a member of the flamingo protein subfamily, which is part of the cadherin superfamily. The flamingo cadherins comprise nine cadherin domains, seven epidermal growth factor-like repeats and two laminin AG-type repeats within the ectodomain (21). Using microarray analysis, 
Table II. Multivariate Cox regression analysis for the prediction of recurrence and progression in non-muscle-invasive bladder cancer.

\begin{tabular}{|c|c|c|c|c|}
\hline \multirow[t]{2}{*}{ Variables } & \multicolumn{2}{|c|}{ Recurrence } & \multicolumn{2}{|c|}{ Progression } \\
\hline & HR $(95 \% \mathrm{CI})$ & P-value & $\operatorname{HR}(95 \% \mathrm{CI})$ & P-value \\
\hline Age ( $<67$ vs. $\geq 67$ years) & $1.018(0.617-1.680)$ & 0.943 & $1.075(0.410-2.819)$ & 0.883 \\
\hline Gender (male vs. female) & $0.954(0.481-1.895)$ & 0.894 & $0.763(0.170-3.433)$ & 0.724 \\
\hline \multicolumn{5}{|l|}{ Grade } \\
\hline G1 & 1 & - & 1 & - \\
\hline G2 & $1.038(0.527-2.044)$ & 0.915 & $1.152(0.280-4.740)$ & 0.844 \\
\hline G3 & $1.110(0.449-2.746)$ & 0.821 & $3.240(0.504-20.834)$ & 0.216 \\
\hline Number of tumors (single vs. multiple) & $1.115(0.680-1.830)$ & 0.666 & $1.108(0.454-2.700)$ & 0.822 \\
\hline Tumor size ( $<3$ vs. $\geq 3 \mathrm{~cm})$ & $1.152(0.709-1.873)$ & 0.567 & $2.428(0.904-6.526)$ & 0.079 \\
\hline Stage (Ta vs. T1) & $0.961(0.481-1.895)$ & 0.905 & $0.644(0.174-2.390)$ & 0.511 \\
\hline Intravesical therapy (No vs. Yes) & $2.646(1.397-5.014)$ & 0.003 & $2.195(0.574-8.397)$ & 0.251 \\
\hline Three-gene risk signature (low vs. high) & $1.519(0.926-2.493)$ & 0.098 & $4.268(1.542-11.814)$ & 0.005 \\
\hline
\end{tabular}

HR, hazard ratio; CI, confidence interval.

Erkan et al reported that CELSR3 was up-regulated in tumor-associated stellate cells compared with inflammationassociated ones. These data were confirmed by mRNA expression, immunoblot analysis, and tissue immunohistochemistry (22). The authors suggested that the up-regulation of CELSR3 in tumors provides a potential drug target, since the protein encoded by this gene is located at the plasma membrane and has noteworthy signaling capabilities (23). It is postulated that these proteins are receptors involved in contact-mediated communication, with the cadherin domains acting as homophilic binding regions and the EGF-like domains involved in cell adhesion and receptor-ligand interactions. Taken together, these data suggest a significant role for $C E L S R 3$ in $\mathrm{BC}$ that warrants further investigation. KIFIA, located on chromosome $2 \mathrm{q} 37$, is a member of the kinesin superfamily of motor proteins. This protein is an anterograde motor protein that transports membranous organelles along the axonal microtubules and is extremely similar to the mouse heavy chain kinesin member $1 \mathrm{~A}$ (KHC) protein $(24,25)$. In the mouse colon, KHC transports the APC protein along microtubules. The suppression of KHC expression eliminates the peripheral translocation of APC and induces the cellular accumulation of $\beta$-catenin, leading to malignant transformation (26). The altered expression of KIFIA and other kinesin superfamily genes has been reported in a variety of human cancers including breast, glioblastoma, and prostate cancer (27-29). A recent study reported that KIFlA showed significant differences in plasma DNA methylation between control and patient samples in lung cancer and suggested a significant potential of molecular detection approaches (30). $\mathrm{COCH}$ is a cell adhesion molecule (31) that maps to human chromosome 14q11.2-13 (32), and is linked with non-syndromic, autosomal dominant hearing loss due to vestibular malfunction with variable penetrance. However, the cancer-related functions of $\mathrm{COCH}$ have yet to be demonstrated. Only one report links $\mathrm{COCH}$ to cancer, and suggests that it is regulated by leukemia inhibitory factor in the uterus at the time of embryo implantation (33).

Frequent recurrence and progression are devastating events for both urologists and $\mathrm{BC}$ patients. As a result, there have been various efforts to develop methods for detecting and predicting the biological behavior of $\mathrm{BC}$. The methods used for evaluation should be convenient and adequate for patients as well as urologists. Economic problems also have to be considered with respect to $\mathrm{BC}$ patients, as the high incidence of recurrence results in considerable costs, which render NMIBC one of the most expensive diseases to treat (34). Progression from NMIBC to MIBC, or metastasis, is not uncommon and is often life-threatening. Efforts geared towards preventing these events are ongoing. Conventional methods include a second TUR, intravesical drug instillation treatment, and early cystectomy $(35,36)$. However, the compliance of patients treated with intravesical drug instillation is poor and cystectomy may lead to severe complications or morbidity (37). On the other hand, the use of the three-gene signature in a clinical setting is beneficial in that management of numerous NMIBC patients is feasible. Therefore, obtaining information regarding disease aggressiveness at the time of initial diagnosis is possible. Assessment of the true malignant potential of NMIBC at the time of diagnosis may change the current schedule of treatment. For instance, it may prioritize high-risk patients for early cystectomy, or urgent cystoscopy, and may delay or prolong the interval between examinations for low-risk patients, thereby improving patient quality of life and outcome. Additionally, this method may be cost-effective for $\mathrm{BC}$ patients as compared to microarray analysis or a panel of markers, simultaneously overcoming the limitations of single marker analysis and the current stage-grading system. 
The exact mechanism underlying the progression of NMIBC driven by the three genes remains to be elucidated. Investigation of these mechanisms may be the subject of future studies. The three-gene signature we identified can be applied clinically. Predictive models, including or excluding any new putative biomarkers, need to show clinically significant improvements in performance to claim any real benefit. Consequently, we are currently recruiting a larger cohort of $\mathrm{BC}$ patients and using long-term follow-up periods in an independent cohort.

In conclusion, this study shows that our three-gene signature is capable of predicting the prognosis of NMIBC and is closely associated with disease progression. Utilization of this technique in clinical practice is likely to improve the follow-up schedule of NMIBC patients. However, introducing this prognostic test for NMIBC into routine clinical practice requires further external validation in a prospective manner using a large number of samples.

\section{Acknowledgements}

The present study was supported by the Basic Science Research Program through the National Research Foundation of Korea (NRF) funded by the Ministry of Education, Science and Technology (2010-0001730).

\section{References}

1. Jemal A, Siegel R, Ward E, Hao Y, Xu J, Murray T and Thun MJ: Cancer statistics. CA Cancer J Clin 58: 71-96, 2008.

2. Ha YS, Kim MJ, Yoon HY, Kang HW, Kim YJ, Yun SJ, Lee SC and Kim WJ: mRNA expression of S100A8 as a prognostic marker for progression of non-muscle-invasive bladder cancer Korean J Urol 51: 15-20, 2010.

3. Sylvester RJ, van der Meijden AP, Oosterlinck W, Witjes JA, Bouffioux C, Denis L, Newling DW and Kurth K: Predicting recurrence and progression in individual patients with stage Ta T1 bladder cancer using EORTC risk tables: a combined analysis of 2596 patients from seven EORTC trials. Eur Urol 49: S466-S477, 2006.

4. Borden LS Jr, Clark PE and Hall MC: Bladder cancer. Curr Opin Oncol 15: 227-233, 2003.

5. Kim WJ, Kim EJ, Kim SK, Kim YJ, Ha YS, Jeong P, Kim MJ, Yun SJ, Lee KM, Moon SK, Lee SC, Cha EJ and Bae SC: Predictive value of progression-related gene classifier in primary non-muscle invasive bladder cancer. Mol Cancer 9: 3, 2010.

6. Shariat SF, Zippe C, Ludecke G, et al: Nomograms including nuclear matrix protein 22 for prediction of disease recurrence and progression in patients with Ta, T1 or CIS transitional cell carcinoma of the bladder. J Urol 173: 1518-1525, 2005.

7. Hong SJ, Cho KS, Han M, Rhew HY, Kim CS, Ryu SB, Sul CK, Chung MK, Park TC and Kim HJ: Nomograms for prediction of disease recurrence in patients with primary $\mathrm{Ta}, \mathrm{T} 1$ transitional cell carcinoma of the bladder. J Korean Med Sci 23: 428-433, 2008.

8. Habuchi T, Marberger M, Droller MJ, Hemstreet GP III, Grossman HB, Schalken JA, Schmitz-Drager BJ, Murphy WM, Bono AV, Goebell P, Getzenberg RH, Hautmann SH, Messing E, Fradet Y and Lokeshwar VB: Prognostic markers for bladder cancer: International Consensus Panel on bladder tumor markers. Urology 66: 64-74, 2005.

9. Babjuk M, Oosterlinck W, Sylvester R, Kaasinen E, Bohle A and Palou-Redorta J: EAU guidelines on non-muscle-invasive urothelial carcinoma of the bladder. Eur Urol 54: 303-314, 2008.

10. Hall MC, Chang SS, Dalbagni G, Pruthi RS, Seigne JD, Skinner EC, Wolf JS Jr and Schellhammer PF: Guideline for the management of nonmuscle invasive bladder cancer (stages Ta, T1, and Tis): 2007 update. J Urol 178: 2314-2330, 2007.

11. Greene FL: The american joint committee on cancer: updating the strategies in cancer staging. Bull Am Coll Surg 87: 13-15, 2002.

12. Bland JM and Altman DG: Transformations, means, and confidence intervals. BMJ 312: 1079, 1996.
13. Kim YJ, Ha YS, Kim SK, Yoon HY, Lym MS, Kim MJ, Moon SK, Choi YH and Kim WJ: Gene signatures for the prediction of response to Bacillus Calmette-Guerin immunotherapy in primary pT1 bladder cancers. Clin Cancer Res 16: 2131-2137, 2010.

14. Chen HY, Yu SL, Chen CH, Chang GC, Chen CY, Yuan A, Cheng CL, Wang CH, Terng HJ, Kao SF, Chan WK, Li HN, Liu CC, Singh S, Chen WJ, Chen JJ and Yang PC: A five-gene signature and clinical outcome in non-small-cell lung cancer. $\mathrm{N}$ Engl J Med 356: 11-20, 2007.

15. Lossos IS, Czerwinski DK, Alizadeh AA, Wechser MA, Tibshirani R, Botstein D and Levy R: Prediction of survival in diffuse large-B-cell lymphoma based on the expression of six genes. N Engl J Med 350: 1828-1837, 2004.

16. Beer DG, Kardia SL, Huang CC, Giordano TJ, Levin AM, Misek DE, Lin L, Chen G, Gharib TG, Thomas DG, Lizyness ML, Kuick R, Hayasaka S, Taylor JM, Iannettoni MD, Orringer MB and Hanash S: Gene-expression profiles predict survival of patients with lung adenocarcinoma. Nat Med 8: 816-824, 2002

17. Skrzypski M, Jassem E, Taron M, Sanchez JJ, Mendez P, Rzyman W, Gulida G, Raz D, Jablons D, Provencio M, Massuti B, Chaib I, Perez-Roca L, Jassem J and Rosell R: Three-gene expression signature predicts survival in early-stage squamous cell carcinoma of the lung. Clin Cancer Res 14: 4794-4799, 2008.

18. Paik S, Shak S, Tang G, Kim C, Baker J, Cronin M, Baehner FL, Walker MG, Watson D, Park T, Hiller W, Fisher ER, Wickerham DL, Bryant J and Wolmark N: A multigene assay to predict recurrence of tamoxifen-treated, node-negative breast cancer. N Engl J Med 351: 2817-2826, 2004.

19. Bol MG, Baak JP, Buhr-Wildhagen S, Kruse AJ, Kjellevold KH, Janssen EA, Mestad O and Ogreid P: Reproducibility and prognostic variability of grade and lamina propria invasion in stages Ta, T1 urothelial carcinoma of the bladder. J Urol 169: 1291-1294, 2003.

20. Murphy WM, Takezawa K and Maruniak NA: Interobserver discrepancy using the 1998 World Health Organization/ International Society of Urologic Pathology classification of urothelial neoplasms: practical choices for patient care. J Urol 168: 968-972, 2002.

21. Wu Q and Maniatis T: Large exons encoding multiple ectodomains are a characteristic feature of protocadherin genes. Proc Natl Acad Sci USA 97: 3124-3129, 2000.

22. Erkan M, Weis N, Pan Z, Schwager C, Samkharadze T, Jiang X, Wirkner U, Giese NA, Ansorge W, Debus J, Huber PE, Friess H, Abdollahi A and Kleeff J: Organ-, inflammation- and cancer specific transcriptional fingerprints of pancreatic and hepatic stellate cells. Mol Cancer 9: 88, 2010.

23. Katoh M: WNT/PCP signaling pathway and human cancer (Review). Oncol Rep 14: 1583-1588, 2005.

24 . Hirokawa N: Kinesin and dynein superfamily proteins and the mechanism of organelle transport. Science 279: 519-526, 1998.

25. Aizawa H, Sekine Y, Takemura R, Zhang Z, Nangaku M and Hirokawa N: Kinesin family in murine central nervous system. J Cell Biol 119: 1287-1296, 1992.

26. Cui H, Dong M, Sadhu DN and Rosenberg DW: Suppression of kinesin expression disrupts adenomatous polyposis coli (APC) localization and affects beta-catenin turnover in young adult mouse colon (YAMC) epithelial cells. Exp Cell Res 280: 12-23, 2002.

27. Ostrow KL, Park HL, Hoque MO, Kim MS, Liu J, Argani P, Westra W, Van Criekinge W and Sidransky D: Pharmacologic unmasking of epigenetically silenced genes in breast cancer. Clin Cancer Res 15: 1184-1191, 2009.

28. Uchiyama CM, Zhu J, Carroll RS, Leon SP and Black PM: Differential display of messenger ribonucleic acid: a useful technique for analyzing differential gene expression in human brain tumors. Neurosurgery 37 (Suppl): S464-S470, 1995.

29. Stearns ME and Wang M: Regulation of kinesin expression and type IV collagenase secretion in invasive human prostate PC-3 tumor sublines. Cancer Res 51: 5866-5875, 1991.

30. Ostrow KL, Hoque MO, Loyo M, Brait M, Greenberg A, Siegfried JM, Grandis JR, Gaither Davis A, Bigbee WL, Rom W and Sidransky D: Molecular analysis of plasma DNA for the early detection of lung cancer by quantitative methylationspecific PCR. Clin Cancer Res 16: 3463-3472, 2010.

31. Tuckwell D: Evolution of von Willebrand factor A (VWA) domains. Biochem Soc Trans 27: 835-840, 1999. 
32. Robertson NG, Skvorak AB, Yin Y, Weremowicz S, Johnson KR, Kovatch KA, Battey JF, Bieber FR and Morton CC: Mapping and characterization of a novel cochlear gene in human and in mouse: a positional candidate gene for a deafness disorder, DFNA9. Genomics 46: 345-354, 1997.

33. Rodriguez CI, Cheng JG, Liu L and Stewart CL: Cochlin, a secreted von Willebrand factor type a domain-containing factor, is regulated by leukemia inhibitory factor in the uterus at the time of embryo implantation. Endocrinology 145: 1410-1418, 2004.

34. Botteman MF, Pashos CL, Redaelli A, Laskin B and Hauser R: The health economics of bladder cancer: a comprehensive review of the published literature. Pharmacoeconomics 21: 1315-1330, 2003.
35. Divrik RT, Yildirim U, Zorlu F and Ozen H: The effect of repeat transurethral resection on recurrence and progression rates in patients with $\mathrm{T} 1$ tumors of the bladder who received intravesical mitomycin: a prospective, randomized clinical trial. J Urol 175: 1641-1644, 2006.

36. Thalmann GN, Markwalder R, Shahin O, Burkhard FC, Hochreiter WW and Studer UE: Primary T1G3 bladder cancer: organ preserving approach or immediate cystectomy? J Urol 172: 70-75, 2004.

37. Ramani VA, Bromage SJ and Clarke NW: A contemporary standard for morbidity and outcome after radical cystectomy. BJU Int 104: 628-632, 2009. 